\title{
Law $\boldsymbol{\&}$ Social Inquiry
}

\section{Journal of the American Bar Foundation Volume 38, Number 3, Summer 2013}

\section{WILEY Blackwell}




\title{
Law \& \\ Social Inquiry
}

Journal of the American Bar Foundation Expanding Knowledge, Advancing Justice Published by Wiley Blackwell

Editor
Review Section Editor

Associate Editors
Laura Beth Nielsen

Howard S. Erlanger

Traci Burch

Victoria Saker Woeste

Christopher W. Schmidt

Jill D. Weinberg

Amanda Ehrhardt

\section{Editorial Board}

\author{
2011-2013 \\ Ana Aparicio, Anthropology, Northwestern University \\ Anthony Chen, Sociology, Northwestern University \\ Eric A. Feldman, Law, University of Pennsylvania \\ Michele B. Goodwin, Law, University of Minnesota \\ Lynne Haney, Sociology, New York University \\ Bernard E. Harcourt, Law \& Political Science, University of Chicago \\ Jerry Kang, Law, University of California \\ Kenneth Mack, Law, Harvard University \\ Michael Leo Owens, Political Science, Emory University \\ Tom Tyler, Psychology, New York University
}

\section{2-2014}

Mario Barnes, Law, University of Califronia-Irvine

Katharine Beckett, Law, Societies \& Justice, University of Washington

Sarah Biddulph, Law, University of Melbourne

Tomiko Brown-Nagin, Law, Harvard University

Laura E. Gómez, Law, University of California, Los Angeles

Joanna Grisinger, Legal Studies, Northwestern University

Anne Morrison Piehl, Economics, Rutgers University

Justin B. Richland, Anthropology, University of Chicago

Francis Shen, Law, University of Minnesota

Sarah Song, Law \& Political Science, University of California at Berkeley

2013-2015

Kenworthey Bilz, Law, University of Illinois

Robert Crutchfield, Sociology, University of Washington

Zev Eigen, Law, Northwestern University

Marie Gottschalk, Political Science, University of Pennsylvania

Amalia Kessler, Law, Stanford University

Doris Marie Provine, Justice \& Social Inquiry, Arizona State University

Kimberly Richman, Legal Studies \& Sociology, University of San Francisco

Jennifer Robbennolt, Law \& Psychology, University of Illinois

Heather Schoenfeld, Sociology, Ohio State University

Stewart Schwab, Law, Cornell University

Jonathan Simon, Law, University of California at Berkeley

David Tanenhaus, Law \& History, University of Nevada, Las Vegas

Anders Walker, Law, Saint Louis University

Keith Whittington, Politics, Princeton University 


\section{Law $\&$ \\ Social Inquiry}

Volume 38, Number 3, Summer 2013

\section{ARTICLES}

"Cultures of Legitimacy and Postcolonial Policing"

Cultures of Legitimacy and Postcolonial Policing: Guest Editor Introduction Beatrice Jauregui

Performances of Police Legitimacy in Rio's Hyper Favela Erika Robb Larkins

In Search of Moral Recognition? Policing and Eudaemonic Legitimacy in Ghana Justice Tankebe

From General to Commissioner to General-On the Popular State of Policing in South Africa

Julia Hornberger

Legitimate Force in a Particularistic Democracy: Street Police and Outlaw Legislators in the Republic of China on Taiwan Jeffrey T. Martin

Beatings, Beacons, and Big Men: Police Disempowerment and Delegitimation in India

Beatrice Jauregui

The Legal Profession as a Social Process: A Theory on Lawyers and Globalization Sida Liu

Botched Executions and the Struggle to End Capital Punishment:

A Twentieth-Century Story

Austin Sarat, Katherine Blumstein, Aubrey Jones, Heather Richard,

Madeline Sprung-Keyser, and Robert Weaver

The Consequences of Culture: Legal History, Labor Law, and the Contributions of Christopher Tomlins

Raymond Hogler

Ideologies in Law Time: The Oxford History of the Laws of England Janet McLean 


\section{Publication Policy}

Law \& Social Inquiry is published quarterly for the American Bar Foundation by Wiley Periodicals, Inc., Commerce Place, 350 Main St., Malden, MA 02148-5020; Tel: 781388 8200; Fax: 7813888210.

The purpose of Law $\mathbb{O}$ Social Inquiry is to promote research and writing dedicated to the study of law, legal institutions, legal processes and individuals' interactions with legal systems, undertaken from a socio-legal perspective. The editors invite the submission of manuscripts that make original contributions to the understanding of sociolegal processes. Law $\mathbb{E}$ Social Inquiry considers both empirical analyses and theoretical studies without restriction as to time or place. Law $\mathcal{E}$ Social Inquiry embraces the broad range of perspectives and methodologies current in contemporary social science and humanities disciplines.

Law $\mathcal{E}$ Social Inquiry is a refereed journal that practices double-blind peer review. Manuscripts deemed appropriate for the journal are evaluated by two or more referees with expertise in the relevant subject matter and methodology. Manuscripts are rendered anonymous prior to review; referees are not identified to authors.

The American Bar Foundation (ABF) is an independent, nonprofit national research institute committed to objective empirical research on law and legal institutions. The Foundation's program of sociolegal research is conducted by an interdisciplinary staff of Research Fellows trained in such diverse fields as law, sociology, psychology, political science, economics, history, and anthropology. The American Bar Foundation is the preeminent resource for lawyers, scholars, and policy makers seeking analyses of the theory and functioning of law, legal institutions, and the legal profession. The Foundation's work is supported by the American Bar Endowment, by The Fellows of the American Bar Foundation, and by grants for particular research projects from private foundations and government agencies. The Foundation (Director Robert L. Nelson) is located at 750 North Lake Shore Drive, 4th floor, Chicago, Illinois 60611. Further information about Foundation programs and activities can be found at: www.americanbarfoundation.org. For information specific to Law $\mathbb{E}$ Social Inquiry choose the publications menu on the ABF website, go directly to www.abfn.org/lawsoc.html, or go to www.wileyonlinelibrary.com.

Manuscripts submitted to Law $\mathbb{E}$ Social Inquiry by ABF Research Fellows are evaluated in the same fashion as all other manuscripts received, and are accorded no special privilege or priority in publication.

ARTICLES: To submit an article manuscript, please go to the Journal's ScholarOne Manuscripts homepage (http:// mc.manuscriptcentral.com/lsi). Log in, or click the "Create Account" option at the top-right corner of the log-in page if you are a first-time user of ScholarOne Manuscripts. After submitting your manuscript, you will receive a confirmation e-mail. You can also access ScholarOne Manuscripts any time to check the status of your manuscript. The Journal will inform you once a decision has been made.

Send general queries to: lsi-abf@abfn.org. The mailing address: Law and Social Inquiry, The American Bar Foundation, 750 North Lake Shore Drive, Suite 400, Chicago, Illinois 60611. Telephone: 312-988-6517. Fax: 312-988-6611.

REVIEW ESSAYS: Review Essays do not undergo traditional peer review, so please do not use ScholarOne Manuscripts to submit your essay.

Send books for review and inquiries regarding review essays to: Howard S. Erlanger, Review Section Editor, Law \& Social Inquiry, Institute for Legal Studies, Law School, University of Wisconsin, Madison, WI 53706.

Telephone: 608-263-7405. Fax: 608-238-8003. E-mail: erlanger@ssc.wisc.edu. Please note that Law $\&$ Social Inquiry publishes review essays and short book notes but not traditional book reviews.

Law $\mathcal{E}$ Social Inquiry will not consider any manuscript concurrently submitted for publication elsewhere. Submission of a manuscript commits the author to publish the manuscript in Law \& Social Inquiry if accepted for publication by the Editors.

Manuscript Preparation and Submission Guidelines: Article manuscripts submitted to Law $\mathbb{E}$ Social Inquiry should be prepared using MS Word. Please use Times New Roman 12pt font for text, notes, and references. Article manuscripts must be double-spaced throughout, including notes and references. Article manuscripts must be accompanied by an abstract of no more than 150 words. LSI strongly prefers submissions to adhere to a 15,000 word limit. If your manuscript is over 15,000 words, please submit a letter with the submission explaining the length. We will allow up to 17,500 words for papers using qualitative, historical, narrative, or multiple methodologies. For complete submissions instructions, please see www.wileyonlinelibrary.com.

Accepted Manuscripts: Manuscripts that are accepted for publication must be brought into full conformity with Law $\mathbb{E}$ Social Inquiry style. Detailed instructions can be found at www.wileyonlinelibrary.com.

Accepted manuscripts are copy edited for style but not substance; authors remain responsible for citation accuracy and for all statements of fact or opinion. Authors are given an opportunity to review edited manuscripts and/or proofs.

Off-Prints to Authors: Free access to the final PDF offprint of articles will be available via Author Services only, an automated system. Please sign up for Author Services if you would like to access your article PDF offprint and to access the other benefits the service offers. Authors are encouraged to sign up for Author Services when their article enters production in order to receive a clear explanation of the benefits, including the ability to access their final article. To sign up, visit http://authorservices.wiley. com/bauthor/.

Republication Rights: It is a condition of publication that authors assign copyright in their articles to the American Bar Foundation. Authors retain rights of re-use, as long as re-use does not include sale or reproduction of the article or any part of it for commercial purposes. These rights apply without needing to seek permission from the Foundation or Wiley Blackwell. In addition, provided that authors give appropriate acknowledgement to the Journal, the American Bar Foundation and Wiley Blackwell, and full bibliographic reference for the Article when it is published, they may use all or part of the article and abstract, without revision or modification, in personal compilations or other publications of their own work.

All requests by third parties to re-use the Article in whole or in part will be handled by Wiley Blackwell. Any permission fees will be retained by the Journal. All requests to adapt substantial parts of the Article in another publication (including publication by Wiley Blackwell) will be subject to the author's approval. 
Law $\mathcal{E}$ Social Inquiry (ISSN 0897-6546[print], ISSN 1747-4469[online]) is published quarterly on behalf of the American Bar Foundation by Wiley Subscription Services, Inc., a Wiley Company, 111 River St., Hoboken, NJ 07030-5774.

Information for subscribers: Law $\mathbb{E}$ Social Inquiry is published in four issues per year. Institutional subscription prices for 2013 are: Print \& Online: US $\$ 270$ (US), US\$311 (Rest of World), €203 (Europe), $£ 159$ (UK). Prices are exclusive of tax. Asia-Pacific GST, Canadian GST and European VAT will be applied at the appropriate rates. For more information on current tax rates, please go to www.wileyonlinelibrary.com/tax-vat. The price includes online access to the current and all online back files to January 1st 2009, where available. For other pricing options, including access information and terms and conditions, please visit www.wileyonlinelibrary.com/access.

Journal Customer Services: For ordering information, claims and any inquiry concerning your journal subscription please go to www.wileycustomerhelp.com/ask or contact your nearest office.

Americas: Email: cs-journals@wiley.com; Tel: +1 7813888598 or +18008356770 (toll free in the USA \& Canada)

Europe, Middle East and Africa: Email: cs-journals@wiley.com; Tel: +44 (0) 1865778315.

Asia Pacific: Email: cs-journals@wiley.com; Tel: +65 65118000.

Japan: For Japanese speaking support, Email: cs-japan@wiley.com; Tel: +65 65118010 or Tel (toll-free): 00531650480.

Visit our Online Customer Get-Help available in 6 languages at www.wileycustomerhelp.com

Electronic Access: This journal is available online at Wiley Online Library. Visit www.wileyonlinelibrary.com to search the articles and register for table of contents e-mail alerts.

Access to this journal is available free online within institutions in the developing world through the AGORA initiative with the FAO, the HINARI initiative with the WHO and the OARE initiative with UNEPFor information, visit www.aginternetwork.org, www.healthinternetwork.org, www.oarescience.org

Back Issues: Single issues from current and recent volumes are available at the current single issue price from cs-journals@ wiley.com. Earlier issues may be obtained from Periodicals Service Company, 11 Main Street, Germantown, NY 12526, USA. Tel: +1 518537 4700, Fax: +1 518537 5899, Email: psc@periodicals.com

Production Editor: Muhammad Haider Md Sahle (email: LSI@wiley.com)

Mailing: Periodical Postage Paid at Hoboken, $\mathrm{NJ}$ and additional offices.

Postmaster: Send all address changes to LAW \& SOCIAL INQUIRY, Journal Customer Services, John Wiley \& Sons Inc., 350 Main St., Malden, MA 02148-5020.

Abstracting and Indexing Services: Academic Search (EBSCO), Academic Search Premier (EBSCO), Arts \& Humanities Citation Index ${ }^{\circledR}$ (Thomson ISI), Criminal Justice Abstracts (Sage), Current Abstracts (EBSCO), Current Contents ${ }^{\circledR}$ (Thomson ISI), Current Contents $® /$ Social \& Behavioral Sciences (Thomson ISI), Current Law Index (Thomson Gale), EBSCO Legal Collection (EBSCO), EBSCO Sociological Collection (EBSCO), Expanded Academic ASAP (Thomson Gale), Family Index (), Index to Legal Periodicals \& Books (HW Wilson), InfoTrac (), Journal Citation Reports/Social Science Edition (Thomson ISI), LegalTrac (), Proquest 5000 (ProQuest), Proquest Discovery (ProQuest), Proquest Research Library (ProQuest), Social Sciences Citation Index ${ }^{\circledR}$ (Thomson ISI), Social SciSearch ${ }^{\circledR}$ (Thomson ISI), Social Services Abstracts (CSA/CIG), SocINDEX (EBSCO), Sociological Abstracts (CSA/CIG), Student Resource Center College (w/ Academic ASAP), Worldwide Political Sciences Abstracts (CSA/CIG).

Copyright and Photocopying: (C) 2013 American Bar Foundation. All rights reserved. No part of this publication may be reproduced, stored or transmitted in any form or by any means without the prior permission in writing from the copyright holder. Authorization to photocopy items for internal and personal use is granted by the copyright holder for libraries and other users registered with their local Reproduction Rights Organization (RRO), e.g. Copyright Clearance Center (CCC), 222 Rosewood Drive, Danvers, MA 01923, USA (www.copyright.com), provided the appropriate fee is paid directly to the RRO. This consent does not extend to other kinds of copying such as copying for general distribution, for advertising or promotional purposes, for creating new collective works or for resale. Special requests should be addressed to: PermissionsUK@wiley.com

ISSN $0897-6546$ (Print)

ISSN 1747-4469 (Online)

For submission instructions, subscription and all other information visit: www.wileyonlinelibrary.com.

Wiley's Corporate Citizenship initiative seeks to address the environmental, social, economic, and ethical challenges faced in our business and which are important to our diverse stakeholder groups. We have made a long-term commitment to standardize and improve our efforts around the world to reduce our carbon footprint. Follow our progress at www.wiley.com/go/citizenship

Disclaimer: The Publisher, the American Bar Foundation, and the Editors cannot be held responsible for errors or any consequences arising from the use of information contained in this journal; the views and opinions expressed do not necessarily reflect those of the Publisher, the American Bar Foundation, and the Editors, neither does the publication of advertisements constitute any endorsement by the Publisher, American Bar Foundation, and Editors of the products advertised.

Printed in the USA by Sheridan Press 